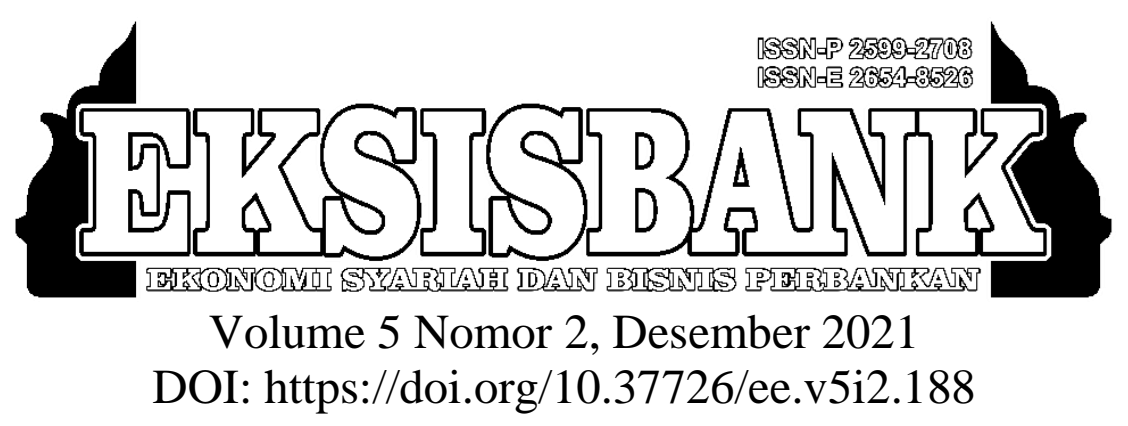

\title{
Pengaruh Pemahaman Nasabah Pada Jenis Produk Terhadap Kelancaran Pembayaran Angsuran Di BMT Niaga Utama Purwakarta
}

\author{
Syanti Herlinawati ${ }^{1}$, Asep Dede Kurnia ${ }^{2}$, Jalaludin ${ }^{3}$ \\ ${ }^{1}$ Sekolah Menengah Kejuruan (SMK) Bina Kerja Purwakarta \\ ${ }^{2,3}$ Sekolah Tinggi Ilmu Ekonomi Syariah (STIES) Indonesia Purwakarta \\ ${ }^{1}$ syantiherlinawati@gmail.com \\ 3 jalaludin@sties-purwakarta.ac.id \\ 2asepjibril93@yahoo.com
}

\begin{abstract}
ABSTRAK
Industri perbankan saat ini tengah mengalami perkembangan yang pesat dimana kegiatan utama dari lembaga keuangan adalah menghimpun dana dan menyalurkan kembali kepada masyarakat dalam bentuk kredit/pembiyaan. Permasalahan yang timbul dari proses pembiayaan adalah pengembalian dana yang yang macet dari nasabah sebagai resiko yang tidak bisa dihindarkan dengan beberapa indokator penyebab seperti hilangnya pemasukan nasabah, bencana yang dialami nasabah, sakit serta kesadaran dan kemauan mengembalikan dana dari nasabah yang didasari oleh pemahaman terhadap kontrak akad pembiayaan. Penelitian ini bertujuan untuk menganalisis pengaruh pemahaman nasabah pada produk mudharabah, produk musyarakah, dan produk murabahah dan untuk menguji pengaruh ratarata pemahaman nasabah terhadap kelancaran pembayaran angsuran di BMT Niaga Utama Purwakarta. Penelitian ini dilakukan dengan metode deskriptif kuantitatif menggunakan sample sebanyak 34 nasabah dari populasi berjumlah 67 nasabah. Penentuan sample penelitian adalah melalui system random sampling dengan skala Likert. Hasil penelitian ini menunjukkan bahwa pemahaman nasabah pada produk mudharabah dinyatakan signifikan terhadap kelancaran pembayaran angsuran dengan nlai $\left.r_{\text {hitung }}(0,84)>r_{\text {tabel }}(0,648)\right)$, sedangkan pemahaman nasabah pada produk musyarakah dinyatakan tidak berpengaruh signifikan terhadap kelancaran pembayaran dengan nilai $\left.r_{\text {hitung }}(0,697)<r_{\text {tabel }}(0,738)\right)$. Adapun untuk pengaruh pemahaman nasabah pada produk murabahah diperoleh angka nilai sig.(2-tailed) sebesar 0,000 yang lebih kecil dari level of significant $(\alpha) 5 \%$ dan dinyatakan signifikan. Sedangkan pengaruh rata-rata diketahui nilai $U_{\text {hitung }}=22>U_{\text {tabel }} 17$ yang menunjukan arti tidak
\end{abstract}


terdapat perbedaan antara pemahaman pada produk mudharabah, musyarakah dan murabahah terhadap kelancaran pembayaran angsuran.

Kata kunci-Mudharabah, Musyarakah, Murabahah, Angsuran.

\begin{abstract}
The banking industry is currently experiencing rapid development where the main activity of financial institutions is to collect funds and channel them back to the public in the form of credit/financing. Problems that arise from the financing process are bad funds from customers as an unavoidable risk with several indicators of causes such as customer income, disasters experienced by customers, awareness and refunds from understanding the financing contract contract. This study aims to analyze the effect of customer understanding on mudharabah products, murabahah products, and murabahah products and to examine the effect of average customer understanding on payment growth at BMT Niaga Utama Purwakarta. This research was conducted by quantitative descriptive method using a sample of 34 customers from a population of 67 customers. Determination of the research sample is through a random sampling system with a Likert scale. The results of this study indicate that the customer's understanding of the mudharabah product is stated to be significant for payment payments with a value of rcount (0.84) > rtable (0.648), while the customer's understanding of the musyarakah product is stated to have no significant effect on payment performance with a value of rcount (0.697) < rtable (0.738). As for the influence of customer understanding of the value of murabahah products, the sig. (2-tailed) number is 0.000 which is smaller than the level of significant ( $\alpha$ ) 5\% and is declared significant. While the effect of the known average value of Ucount $=22>$ Utable 17 shows that there is no difference between understanding the product of mudharabah, musyarakah and murabahah on installment payments.
\end{abstract}

Keywords - Mudharabah, Musyarakah, Murabahah, Installment.

\section{PENDAHULUAN}

Perkembangan sektor perbankan telah tumbuh dengan pesat dan mendominasi kegiatan perekonomian Indonesia. Kegiatan utama dari lembaga keuangan atau pebankan adalah menghimpun dana dari masyarakat melalui simpanan dan menyalurkan kembali dana tersebut kepada masyarakat umum dalam bentuk kredit/pembiyaan. Penyaluran dana dengan metode kredit/pembiyaan yang diberikan kepada masyarakat mewajibkan debitur mengembalikan dana dengan tambahan keuntungan untuk lembaga. Dalam lembaga keungan konvensional pengambilan keuntungan tersebut dengan penerapan system bunga, sedangkan dalam lembaga keuangan Syariah system yang diterapkan adalah bagi hasil (Lisdawami and Mawardi 2017).

Produk pembiayaan yang dilakukan oleh Lembaga keuangan Syariah pada prinsipnya adalah dengan menggunakan akad-akad yang disesuaikan dengan jenis kebutuhan yang diajukan seperti akan murobahah, musyarokah, ijarah dan mudhorobah. hal ini sebagaimana disampaikan oleh Abrar bahwa pembiayaan dalam lembaga keuangan syariah bermakna pemberian dana atau penyaluran dana kepada masyarakat untuk mendukung usaha dan kebutuhannya dalam investasi yang sedang dijalankan baik usaha yang dikelola pribadi maupun dikelola secara kerjasama. Hal ini sebagaimana Undang-undang nomor 7 tahun 1992 tentang perbankan dan telah diubah menjadi Undang-undang nomor 10 
tahun 1998 tentang Perbankan pada pasal 1 nomor 12 disebutkan bahwa "Pembiayaan sesuai asas syariah adalah menyediakan dana atau tagihan yang setara dengan hal tersebut berdasarkan perjanjian antara bank dengan nasabah yang mengharuskan pihak yang memperoleh dana untuk mengembalikan dana tersebut pada saat jatuh tempo dengan akad mudharabah (bagi hasil)". Sedangkan pada nomor 13 dijelaskan kembali bahwa "prinsip syariah adalah kesepakatan sesuai dengan syariah antara bank dengan dengan nasabah untuk simpanan dan membiayai usaha, atau usaha lainnya sesuai dengan syariah, diantaranya pembiayaan bagi hasil (mudharabah), pembiayaan penyertaaan modal (musyarakah), jual beli murni (murabahah) atau pembiayaan dengan sewa murni tanpa pilihan (ijarah), atau dengan pilihan berpindahnya hak milik atas suatu barang yang disewa dari pihak bank oleh pihak lain" (Hutagalung et al. 2021).

Pada praktik dilapangan, akan pembiayan disamping sebagai usaha lembaga dalam mengelola modal dan usaha untuk mendatangkan keuntungan, akad pembiayaan juga memiliki resiko tidak kembalinya modal sesuai dengan waktu yang dijadwalkan seperti nasabah pembiayaan macet. Upaya-upaya untuk meminimalisir kemacetan pengembalian dana dari pihak nasabah menjadi fokus yang tidak bisa abaikan dimuali dari selektif dan prinsip kehati-hatian dalam memebrikan kesepakatan pembiayaan, pengecekan data pendukung dan kemampuan pengembalian biaya dari nasabah hingga analisis solutif jika terjadi kemacetan pengembalian (Bakry and Masse 2020).

Beberapa indikator yang dapat menimbulkan kemacetan pengembalian dana secara umum adalah hilangnya sumber pemasukan nasabah, kejadian tak terduga yang dialamai oleh nasabah seperti musibah dan sakit, bencana yang dialamai oelh nasabah serta kesadaran nasahan akan kemauan mengembalikan dana yang didasari oleh kurangnya pemahaman terhadap kontrak akad yang dibuat dengan perbankan.

Kondisi seperti uaraian diatas sebagaimana dialami oleh BMT Niaga Utama Purwakarta yang mengalami kondisi kemacetan pengembalian dana pembiayaan dari naasabah. Tercatat sebanyak $50,7 \%$ dari jumlah anggota BMT memiliki akad pembiayaan yang macet. Indikator yang dianalisis sebagai faktor yang mendorong kemacetan pengembalian dana pembiayaan tersebut adalah kurangnya pemahaman dari nasabah terhadap konsep dan prinsip dari akad pembiayaan. Seperti akad pembiayaan mudharabah, akad pembiayaan musyarakah dan akad pembiayaan murabahah.

Diketahui bahwa Non Performing Financing (NPF) dari jumlah nasabah BMT Niaga Utama Purwakarta yakni 67 nasabah yang memiliki akad pembiayaan dengan akad yang berbeda seperti akad murabahah, musyarakah dan mudhorobah tercatat sebanyak 34 nasabah mengalami kemacetan. Dari beberapa indikator yang dianalisis sebagai pemicu macetnya pengembalian tersebut salah satunya adalah indikator pemahaman nasabah terhadap produk pembiayaan yang dipilih. Hal ini dimulai dari sikap nasabah yang kurang terbuka terhadap jumlah pendapatan yang diterima nasabah dan pengeluaran resiko nasabah pada awal proses akad transaksi pembiayaan (Alhifni and Huda 2015).

Berdasarkan latar belakang permasalahan yang diuraikan diatas, maka rumusan penelitian yang dibahas pada penelitian ini adalah untuk menganalisis pengaruh pemahaman nasabah pada produk mudharabah dan pemahaman pada produk musyarakah terhadap kelancaran pembayaran angsuran di BMT Niaga Utama Purwakarta, untuk menganalisis pengaruh pemahaman 
nasabah pada produk murabahah terhadap kelancaran pembayaran angsuran di BMT Niaga Utama Purwakart, serta menganalisis perbedaan pengaruh rata-rata pemahaman nasabah pada produk mudharabah, musyarakah dan murabahah di BMT Niaga Utama Purwakarta.

\section{TINJAUAN PUSTAKA}

\section{A. Pembiayaan Mudharabah}

\section{Pengertian}

Mudharabah berasal dari kata dharb, berarti memukul atau berjalan. Pengertian memukul atau berjalan ini lebih tepatnya adalah proses seseorang memukulkan kakinya dalam menjalankan usaha. Secara teknis, alMudharabah adalah akad kerja sama usaha antara dua pihak di mana pihak pertama (shohibul maal) menyediakan $100 \%$ modal, sedangkan pihak lainnya menjadi pengelolola. Keuntungan usaha secara mudharabah dibagi menurut kesepakatan yang dituangkan dalam kontrak, sedangkan apabila rugi ditanggung pemilik modal selama kerugian itu bukan akibat kelalaian si pengelola. Seandainya kerugian itu diakibatkan karena kecurangan atau kelalaian si pengelola, si pengelola harus bertanggung jawab atas kerugian itu. Para Ulama Fiqh mendefinisikan Mudharabah atau Qiradh dengan Pemilik modal (investor) menyerahkan modalnya kepada pekerja (pedagang) untuk diperdagangkan, sedangkan keuntungan dagang itu menjadi milik bersama dan dibagi menurut kesepakatan (Usanti 2013).

Dengan demikian dapat disimpulkan bahwa pembiayaan mudharabah adalah kerja sama antara pihak pertama memberikan seluruh modal dan disebut sebagai shohibul mal sedangkan pihak yang lain sebagai pengelola modal (mudharib).

\section{Landasan Syari'ah Pembiayaan Mudharabah}

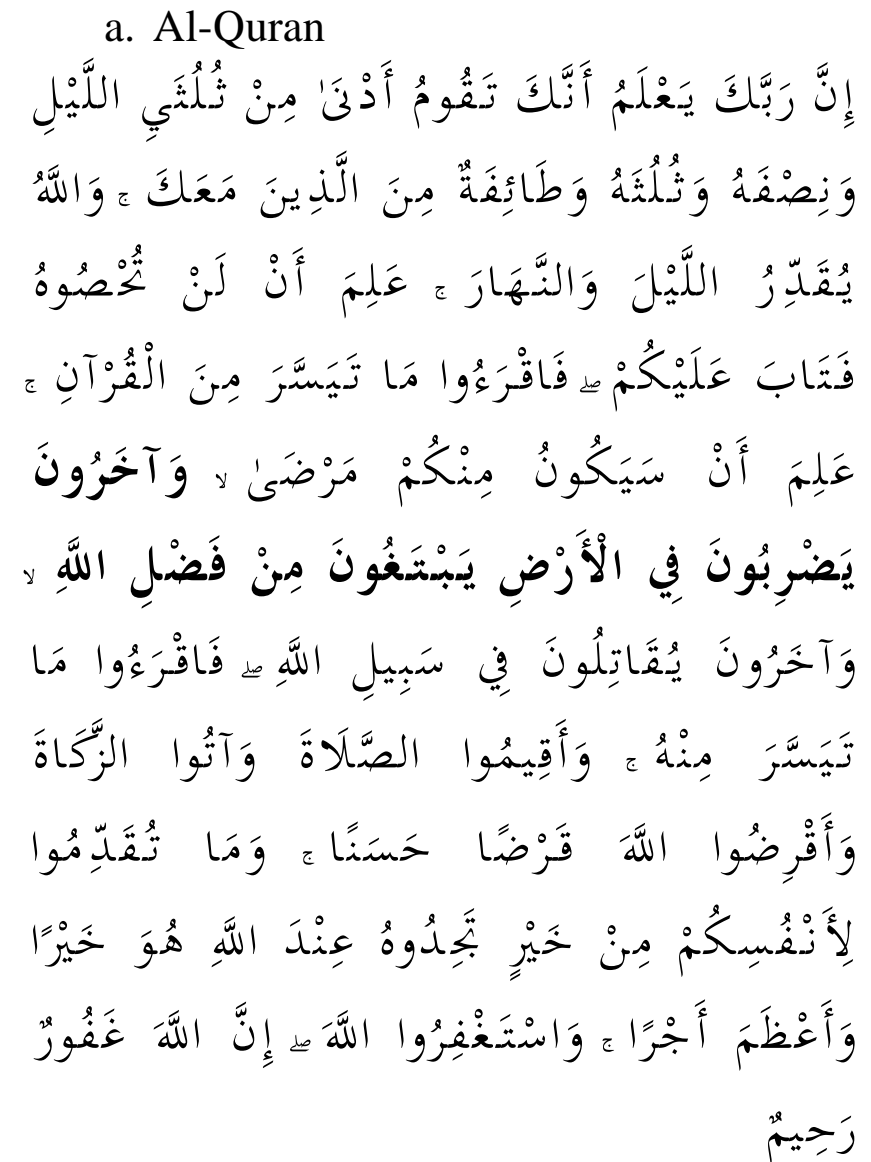

Sesungguhnya Tuhanmu mengetahui bahwasanya kamu berdiri (sembahyang) kurang dari dua pertiga malam, atau seperdua malam atau sepertiganya dan (demikian pula) segolongan dari orangorang yang bersama kamu. Dan Allah menetapkan ukuran malam dan siang. Allah mengetahui bahwa kamu sekali-kali tidak dapat menentukan batas-batas waktu-waktu itu, maka Dia memberi keringanan kepadamu, karena itu bacalah apa yang mudah (bagimu) dari Al Quran. Dia mengetahui bahwa akan ada di antara kamu orang-orang yang sakit dan orangorang yang berjalan di muka bumi mencari sebagian karunia Allah; dan orang-orang yang lain lagi berperang di jalan Allah, maka bacalah apa yang mudah (bagimu) dari Al Quran dan dirikanlah sembahyang, tunaikanlah zakat dan berikanlah pinjaman kepada Allah 
pinjaman yang baik. Dan kebaikan apa saja yang kamu perbuat untuk dirimu niscaya kamu memperoleh (balasan)nya di sisi Allah sebagai balasan yang paling baik dan yang paling besar pahalanya. Dan mohonlah ampunan kepada Allah; sesungguhnya Allah Maha Pengampun lagi Maha Penyayang. (al-Muzzammil:20) (Al-Hadi Al-Quran Terjemahan Per Kata Latin Dan Kode Tajwid 2013)

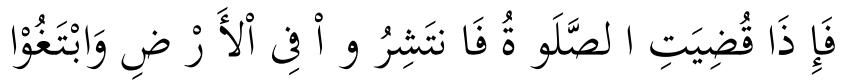

$$
\text { مِنْ فَضْلِ } 1 \text { اللهِ. }
$$

"Apabila telah ditunaikan sholat maka bertebarlah kamu dimuka bumi dan carilah karunia Allah SWT" (Q.S alJumuah: 10) (Kementerian Agama 2010)

\section{b. Al-Hadits}

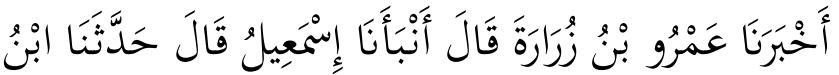
عَوْنٍ قَالَ كَانَ عُحَمَّدٌ يَقُولُ الْأَْْضُ عِنْدِي رِثْلُ مَالِ

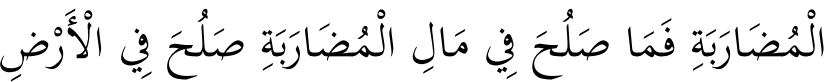

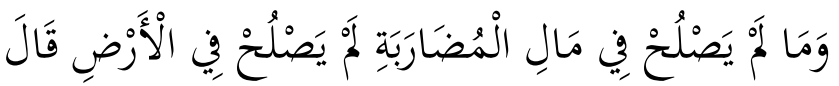

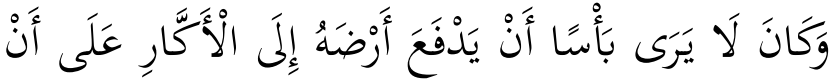

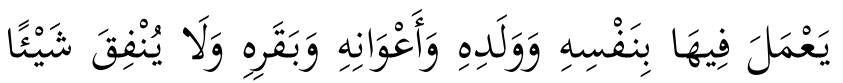

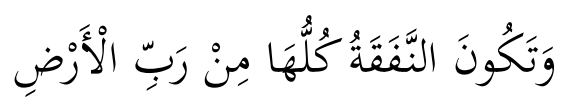

Telah mengabarkan kepada kami ['Amru bin Zurarah] telah memberitakan kepada kami [Isma'il] telah menceritakan kepada kami [Ibnu 'Aun], dia berkata; [Muhammad] pernah berkata; "Tanahku seperti harta Mudharabah (kerjasama dagang dengan memberikan saham harta atau jasa), apa yang layak untuk harta mudharabah maka layak untuk tanahku dan apa yang tidak layak untuk harta mudharabah maka tak layak pula untuk tanahku. Dia memandang tidak mengapa jika dia menyerahkan tanahnya kepada pembajak tanah agar dikerjakan oleh pembajak tanah sendiri, anaknya dan orang-orang yang membantunya serta sapinya, pembajak tidak memberikan biaya sedikitpun, dan pembiayaannya semua dari pemilik tanah." (Sunan_Nasai/3867) (An-Nasa'i, n.d.).

\section{Rukun Pembiayaan Mudharabah:}
a. Orang yang berakad
b. Pemilik modal/ Shahibul maal
c. Pelaksana atau usahawan/ Mudharib
d. Modal/ maal
e. Kerja atau usaha/ dharabah
f. Keuntungan bagi hasil
g. Shighat/ ijab Qabul

\section{Jenis-Jenis Pembiayaan Mudharabah}

Secara Umum, Mudharabah terbagi atas dua jenis, yaitu mudharabah mutlaqah dan mudharabah muqayyadah.

a. Mudharabah Mutlaqah

Bentuk kerja sama antara shahibul maal dan mudharib yang cangkupnya sangat luas dan tidak dibatasi oleh spesifikasi jenis usaha, waktu dan daerah bisnis.

b. Mudharabah Muqayyadah

Mudharabah Muqayyadah atau sering disebut juga dengan istilah restrited mudharabah/specified mudharabah adalah kebalikan dari mudharabah mutlaqah. Si mudharib dibatasi jenis usaha waktu dan tempat usaha. Adanya pembatasan ini seringkali mencerminkan kecenderungan umum si shahibul maal dalam memasuki jenis dunia usaha (Romdhoni and Sari 2018).

\section{Aplikasi dalam Perbankan}

Mudharabah biasanya diterapkan pada produk-produk pembiayaan dan pendanaan.

Bagan 2.1 


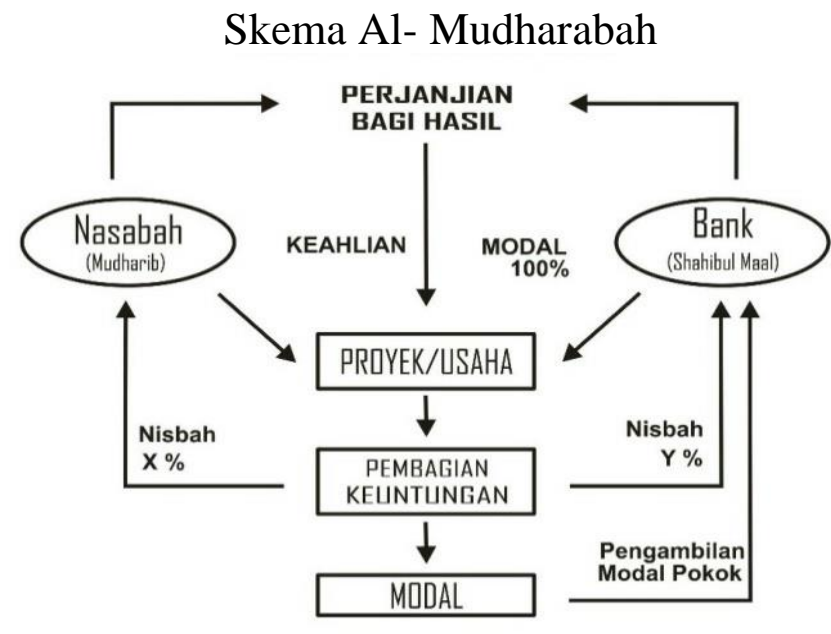

Sumber: Muhammad syafii Antonio, Bank syari'ah.

Berdasarkan pada alu diatas dapat difahami bahwa akad mudharabah merupakan (terikat) akad perjanjian dari anggota kepada BMT (Koperasi) dengan sistem bagi hasil, dimana BMT (Koperasi) dibatasi dalam penggunaan dananya. Besarnya bagi hasil dilakukan dimuka dengan nisbah tertentu seperti untuk usaha kecil mikro (UKM) sentral dan lain-lain (Hidayat 2013).

\section{B. Pembiyaan Musyarakah}

Pengertian musyarakah (syirkah atau syarikah atau serikat atau kongsi) adalah bentuk umum dari usaha bagi hasil dimana dua orang atau lebih menyumbangkan pembiayaan dan manajemen usaha, dengan proporsi bisa sama atau tidak. Keuntungan dibagi sesuai dengan kesepakatan antara para mitra dan kerugian akan dibagikan menurut proporsi modal. Transaksi musyarakah dilandasi adanya keinginan dari angota/ nasabah dan pengurus lembaga keuangan untuk memulai kerjasama, para pihak yang bekerja sama untuk meningkatkan nilai asset yang mereka miliki secara bersama-sama dengan memadukan seluruh sumber daya (Hamidah and Yandono 2016).
Landasan hukum dari akad pembiayaan Musyarakah salah satunya terdapat pada potongan ayat surat an-nisa berikut

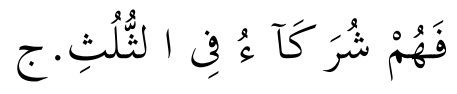

"Maka mereka berserikat pada sepertiga" (An-Nisaa : 12)

Dalam surah An-Nisaa menunjukkan bahwa dalam Al-Quran juga dijelaskan tentang pengakuan Allah akan adanya perserikatan dalam kepemilikan harta, tetapi dalam surah An-Nisaa 12 perkongsian secara otomatis karena waris, dan terjadi karena adanya kesepakan/ akad.

\section{Pembiyaan Murabahah}

\section{Pengertian}

Bai al-Murabahah adalah jual beli barang pada harga asal dengan tambahan keuntungan yang disepakati. Dalam Bai Al-Murabahah penjual harus memberitahu harga produk yang ia beli dan menentukan tingkat keuntungan sebagai tambahannya. Misalnya, pedagang eceran membeli computer dari grosir dengan harga $\mathrm{Rp}$ 10.000.000,00, kemudian ia menambahkan keuntungan sebesar Rp 750.000,00 dan ia menjual kepada si pembeli dengan harga Rp 10.750.000,00. Pada umumnya, si pedagang eceran tidak akan memesan dari grosir sebelum ada pesanan dari nasabah.

\section{Dasar Hukum}

Landasan hukum dari akad murobahah ini salah satunya terdapat pada ayat al-Quran dan al hadits berikut;

$$
\text { وَوأَحَلَّ اللهُ ا لْبَيْعَ وَ حَرَّ مَ ا لور بَوَا }
$$

"Allah telah menghalalkan jual beli dan mengharamkan riba" (al-Baqarah :275)

Hadits yang diriwayatkan dari Suhaib arRumi ra. bahwa Rasulullah SAW bersabda, "Tiga hal yang didalamnya terdapat 
keberkahan: jual beli secara tangguh, mugaradhah (mudharabah), dan mencampur gandum dengan tepung untuk keperluan rumah tangga bukan untuk dijual." (HR. Ibnu Majah)

\section{Syarat BaI al-Murabahah}

Syarat akad murabahah adalah sebagai berikut:

a. Syarat yang berakad (baitu dan mustari) cakap hukum dan tidak dalam keadaan terpaksa

b. Barang yang diperjualbelikan (maba) tidak termasuk barang yang haram dan jenis maupun jumlahnya jelas

c. Harga barang (tsaman) harus dinyatakan secara trasparan (harga pokok dan komponen keuntungan) dan cara pembayaran disebutkan dengan jelas

d. Pernyataan serah terima (ijab qobul) harus jelas dengan menyebutkan secara spesifik pihak-pihak yang berakad (Dewi and Astari 2018).

\section{Manfaat BaI al-Murabahah}

Sesuai dengan sifat bisnis (tijaroh), transaksi bai al-murabahah memiliki beberapa manfaat, demikian juga risiko yang harus diantisipasi. Bai murabahah memberikan banyak manfaat kepada bank syari'ah maupun lembaga keuangan syari'ah lainnya. Diantaranya:

a. Adanya keuntungan yang muncul dari selisih harga beli dari penjual dengan harga jual kepada nasabah.

b. Sistem bai murabahah juga sangat sederhana, hal tersebut memudahkan penanganan administrasinya di bank syari'ah

\section{Resiko Murabahah}

Selain murabahah memiliki manfaat atau keuntungan yang dijelaskan sebelumnya, akad murabahah juga terdapat beberapa resiko yang harus di antisipasi oleh pihak lembaga keuangan syari'ah, diantaranya resiko yang ditimbulkan adalah sebagai berikut:

a. Defaul atau kelalaian : nasabah sengaja tidak membayar angsuran

b. Fluktasi harga komparatif. Ini terjadi bila harga suatu barang dipasar naik setelah bank membelikannya untuk nasabah. Bank tidak bisa mengubah harga jual beli tersebut

c. Penolakan nasabah : barang yang dikirim bisa saja ditolak oleh nasabah karena berbagai sebab. Bisa jadi karena rusak dalam perjalanan sehingga nasabah tidak mau menerimanya. Karena itu, sebaiknya dilindungi dengan asuransi. Kemungkinan lain karena nasabah merasa spesifikasi barang tersebut berbeda dengan yang ia pesan. Bila bank telah menandatangani kontrak pembelian dengan penjualnya, barang tersebut menjadi milik bank. Dengan demikian bank mempunyai resiko untuk menjual kepada pihak lain.

d. Di jual. Karena bai murabahah bersifat jual beli dengan utang, maka ketika kontrak ditandatangani, barang tersebut menjadi milik nasabah. Nasabah bebas melakukan apa pun terhadap aset miliknya tersebut, termasuk untuk menjualnya.

Bagan 2.2

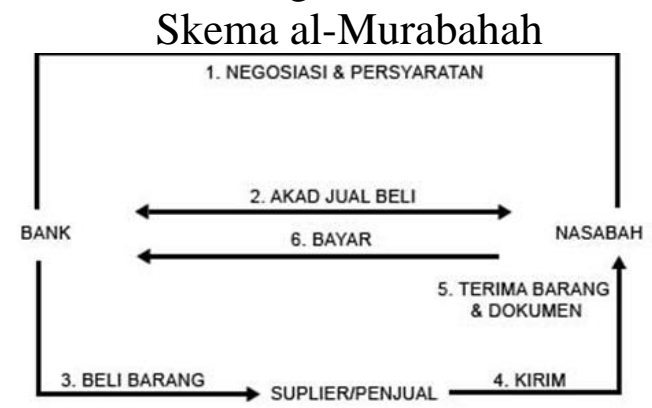

D. Perbandingan Penelitian Terdahulu

EKSISBANK (Ekonomi Syariah dan Bisnis Perbankan), Volume 5, Nomor 2, Desember 2021 
Penelitian tentang pengaruh pemahaman nasabah pada jenis produk terhadap kelancaran pembayaran angsuran, sudah lumayan banyak dilakukan oleh penelitia sebelumnya seperti yag dilakukan oleh :

1. Analisis Solutif Penyelesaian

Pembiayaan Bermasalah di Bank Syariah:

Kajian Pada Produk Murabahah di Bank Muamalat Indonesia Banda Aceh (Ibrahim and Rahmati 2017)

Artikel ini bertujuan untuk mengkaji faktor-faktor penyebab terjadinya pembiayaan bermasalah di Bank Muamalat Indonesia (BMI) Banda Aceh dan kebijakan yang diambil untuk menyelesaikan persoalan tersebut. Secara khusus, artikel ini juga mengkaji keefektifan kebijakan tersebut dalam mereduksi pembiayaan bermasalah di BMI Banda Aceh. Penelitian ini diharapkan dapat menjadi framework atau model bagi bank syariah lain yang memiliki permasalahan yang sama. Data untuk penelitian ini dikumpulkan melalui wawancara mendalam dan studi dokumentasi yang kemudian dianalisis secara kualitatif. Hasil penelitian menunjukkan bahwa faktor penyebab pembiayaan murabahah bermasalah berasal dari 1) nasabah, 2) internal bank dan 3) faktor fiktif. Kebijakan yang diterapkan sangat komprehensif mulai dari pencegahan sampai dengan penyelesaian. Teknis penyelesaian dilakukan dengan metode on the spot, somasi, penagihan, restrukturisasi, penjualan jaminan, dan melakukan write off serta adanya penetapan terhadap denda. Selain itu, BMI juga mempunyai pola-pola kebijakan internal yang secara langsung tidak diatur secara detail oleh otoritas keuangan seperti pembentukan tim remedial yang khusus menangani pembiayaan bermasalah.

Perbedaan penelitian terdahulu dengan penelitian saat ini adalah pertama, lokasi penelitian terdahulu di Bank Muamalat Indonesia Banda Aceh, sedangkan penelitian saat ini di BMT Niaga Utama Purwakarta. Kedua, jenis penelitian terdahulu menggunakan kualitatif, sedangkan penelitian saat ini menggunakan jenis penelitian kuantitatif. Ketiga, objek kajian penelitian terdahulu mengkaji tentang solusi penyelesaian pembiayaan murabahah yang bermasalah, sedangkan penelitian saat ini menguji atau mengkaji pengaruh pembiayaan mudharabah, musyarakah dan murabahah terhadap kelancaran pembayaran angsuran.

2. Analisis Pengaruh Prasyarat Kredit (5c) Terhadap Kelancaran Pembayaran Angsuran Nasabah Di Bank Kalsel Unit Sentra Antasari Banjarmasin (Apriana, Artiningsih, and Irwansyah 2017)

Tujuan penelitian ini untuk membuktikan pengaruh Kredit Prasyarat (5C) secara parsial terdiri dari Karakter $\left(\mathrm{X}_{1}\right)$, Kapasitas $\left(\mathrm{X}_{2}\right)$, Modal $\left(\mathrm{X}_{3}\right)$, Agunan $\left(\mathrm{X}_{4}\right)$, Kondisi Perekonomian $\left(\mathrm{X}_{5}\right)$ terhadap Kelancaran Pembayaran (Y) Angsuran Nasabah Bank Kalsel Unit Sentra Antasari Banjarmasin, membuktikan adanya pengaruh Prasyarat Kredit (Karakter, Kapasitas, Modal, Agunan, Kondisi Perekonomian) secara simultan terhadap kelancaran Pembayaran (Y) Cicilan Nasabah di Bank Kalsel Unit Sentra Antasari Banjarmasin dan variabel pembuktian (Karakter , Capacity, Capital, Collateral, Conditions of Economy) yang berpengaruh paling signifikan terhadap Kelancaran Pembayaran (Y) Cicilan Nasabah pada Bank Unit Sentra Antasari Banjarmasin Kalimantan Selatan. Populasi penelitian adalah Nasabah Bank Unit Sentra Antasari Banjarmasin Kalimantan Selatan yang berjumlah 130 orang. Teknik pengambilan sampel yang digunakan adalah sampling jenuh. Pengumpulan data menggunakan kuesioner yang dirancang menggunakan skala likert level 1-5. Analisis data menggunakan model struktural SPSS. Hasil pengujian 
membuktikan 1). Karakter $\left(\mathrm{X}_{1}\right)$ berpengaruh signifikan secara parsial terhadap Kelancaran Pembayaran (Y) Cicilan Nasabah di Bank Unit Sentra Antasari Banjarmasin Kalimantan Selatan dengan pengaruh besar 25,3\%. 2). Kapasitas $\left(\mathrm{X}_{2}\right)$ berpengaruh signifikan secara parsial terhadap kelancaran Pembayaran (Y) Angsuran Nasabah di Bank Unit Sentra Antasari Banjarmasin Kalimantan Selatan terhadap kinerja pegawai PT Bank Kalsel dengan pengaruh yang besar sebesar $26,7 \%$. 3). Modal $\left(X_{3}\right)$ secara parsial berpengaruh tidak signifikan terhadap Kelancaran Pembayaran (Y) Angsuran Nasabah pada Bank Unit Sentra Antasari Banjarmasin Kalimantan Selatan (1,1\%). 4). Agunan $\left(\mathrm{X}_{4}\right)$ berpengaruh signifikan secara parsial terhadap kelancaran Pembayaran (Y) Cicilan Nasabah pada Bank Unit Sentra Antasari Banjarmasin Kalimantan Selatan terhadap pengaruh sebesar 27,5\%. 5). Kondisi Ekonomi $\left(\mathrm{X}_{5}\right)$ namun tidak berpengaruh signifikan secara parsial terhadap Kelancaran Pembayaran (Y) Angsuran Nasabah di Bank Unit Sentra Antasari Banjarmasin Kalimantan Selatan (0,7\%). 6). Prasyarat Kredit (5C) secara simultan berpengaruh tidak signifikan terhadap kelancaran Pembayaran (Y) Cicilan Nasabah di Bank Unit Sentra Antasari Banjarmasin Kalimantan Selatan (18,5\%) karyawan PT Bank Kalsel terhadap kinerja dengan pengaruh besar $26,7 \%$ Pelatihan berpengaruh signifikan terhadap Kinerja Pegawai PT Bank Kalsel dengan pengaruh besar 24,34\% 3) Kompensasi Keuangan berpengaruh signifikan terhadap kinerja pegawai PT Bank Kalsel dengan pengaruh besar $31,11 \%$. Variabel yang paling dominan adalah variabel Jaminan (X4) terhadap kelancaran Pembayaran Angsuran Nasabah Unit Bank Sentra Antasari Banjarmasin di Kalimantan Selatan.

Perbedaan penelitian terdahulu dengan penelitian saat ini adalah pertama, lokasi penelitian terdahulu di Bank Kalsel Unit Sentra Antasari Banjarmasin, sedangkan penelitian saat ini di BMT Niaga Utama Purwakarta. Kedua, variable yang digunakan pada penelitian terdahulu Prasyarat Kredit (5c) terdiri dari Karakter $\left(\mathrm{X}_{1}\right)$, Kapasitas $\left(\mathrm{X}_{2}\right)$, Modal ( $\left.\mathrm{X}_{3}\right), \quad$ Agunan $\left(\mathrm{X}_{4}\right), \quad$ Kondisi Perekonomian $\left(\mathrm{X}_{5}\right)$ dan variable Kelancaran Pembayaran $(\mathrm{Y})$, sedangkan penelitian saat ini menggunakan variable pemahaman nasabah terdiri dari Pembiayaan Mudharabah $\left(\mathrm{X}_{1}\right)$, Pembiayaan Musyarakah $\left(\mathrm{X}_{2}\right)$, dan Pembiayaan Murabahah $\left(\mathrm{X}_{3}\right)$ pada jenis produk, serta Variabel kelancaran pembayaran angsuran (Y) di BMT Niaga Utama Purwakarta. Ketiga, objek kajian penelitian terdahulu mengkaji tentang Prasyarat Kredit (5c) Terhadap Kelancaran Pembayaran Angsuran, sedangkan penelitian saat ini menguji atau mengkaji pengaruh pembiayaan mudharabah, musyarakah dan murabahah terhadap kelancaran pembayaran angsuran. Keempat, Teknik pengambilan sampel pada penelitia hterdahulu menggunakan sampling jenuh, dan jumlah sampel yang diambil pada penelitian terdahulu sebanyak 130 orang, sedangkan Teknik pengambilan sampel pada penelitian ini menggunakan teknik purposive random sampling, dan jumlah sampel yang diambil pada penelitian ini sebanyak 34 responden.

3. Pengaruh Pinjaman Dana Dan Jenis Usaha Terhadap Kelancaran Pembayaran Kredit Di Bank BTN Madiun (Natalia, Utomo, and Murwani 2019)

Penelitian ini untuk membuktikan pengaruh pinjaman dana, jenis usaha serta pengaruh secara simultan pinjaman dana dan jenis usaha terhadap kelancaran pembayaran kredit di Bank BTN Madiun. Jenis penelitian ini explanatory research dengan desain asosiatif kausal. Teknik pengambilan sampel total sampling dengan sampel 98 orang. 
Teknik pengumpulan data menggunakan kuesioner. Hasil penelitian menunjukkan : (1) pinjaman dana berpengaruh negatif terhadap kelancaran pembayaran kredit di Bank BTN Madiun. (2) Jenis usaha berpengaruh positif signifikan terhadap kelancaran pembayaran kredit di Bank BTN Madiun. Dan (3)Pinjaman dana dan jenis usaha berpengaruh simultan terhadap kelancaran pembayaran kredit di Bank BTN Madiun. Kata Kunci : Pinjaman Dana, Jenis Usaha, Kelancaran Pembayaran Kredit.

Perbedaan penelitian terdahulu dengan penelitian saat ini adalah pertama, lokasi penelitian terdahulu di Bank BTN Madiun, sedangkan penelitian saat ini di BMT Niaga Utama Purwakarta. Kedua, variable yang digunakan pada penelitian terdahulu pinjaman dana $\left(\mathrm{X}_{1}\right)$ dan jenis usaha $\left(\mathrm{X}_{2}\right)$, serta kelancaran pembayaran kredit (Y) Di Bank BTN Madiun, sedangkan penelitian saat ini menggunakan variable pemahaman nasabah (X) terdiri dari Pembiayaan Mudharabah $\left(\mathrm{X}_{1}\right)$, Pembiayaan Musyarakah $\left(\mathrm{X}_{2}\right)$, dan Pembiayaan Murabahah $\left(\mathrm{X}_{3}\right)$ pada jenis produk, serta Variabel kelancaran pembayaran angsuran (Y) di BMT Niaga Utama Purwakarta. Ketiga, objek kajian penelitian terdahulu mengkaji tentang pengaruh pinjaman dana dan jenis usaha terhadap kelancaran pembayaran kredit Di Bank BTN Madiun, sedangkan penelitian saat ini menguji atau mengkaji pengaruh pembiayaan mudharabah, musyarakah dan murabahah terhadap kelancaran pembayaran angsuran. Keempat, Teknik pengambilan sampel pada penelitian terdahulu menggunakan sampling slovin, dan jumlah sampel yang diambil pada penelitian terdahulu sebanyak 98 orang, sedangkan Teknik pengambilan sampel pada penelitian ini menggunakan teknik purposive random sampling, dan jumlah sampel yang diambil pada penelitian ini sebanyak 34 responden.
4. Faktor-Faktor yang Mempengaruhi Kelancaran Pengembalian Kredit Berpenghasilan Tetap (Briguna Kretap) (Studi Kasus pada PT. BRI KC Pondok Gede) (Singgih, Mardiana, and others 2018)

Tujuan penelitian ini untuk mengidentifikasi karakteristik debitur Briguna Kretap pada BRI KC Pondok Gede berdasarkan tingkat kelancaran pengembalian kreditnya dan menganalisis factor-faktor yang berpengaruh nyata terhadap tingkat kelancaran pengembalian Briguna Kretap pada BRI KC Pondok Gede. Penelitian ini menggunakan metode studi kasus yang dilakukan di BRI Cabang Pondok Gede dengan sampel sebanyak 84 orang dengan tekhnik pengambilan simple random sampling. Jenis data yang dikumpulkan adalah data primer dan data sekunder. Sedangkan metode yang digunakan dalam analisis data adalah dengan Regresi Linear berganda serta pengujian hipotesis secara parsial maupun simultan. Berdasarkan hasil pengamatan dapat disimpulkan bahwa karakteristik responden debitur Briguna Kretap BRI Cabang Pondok Gede, baik responden lancer maupun menunggak sebagian besar adalah lulusan SMA, Jumlah tanggungan dalam keluarga sebagian besar berjumlah tiga orang. Mereka sebagian besar mengakses dengan masa pengembalian 60 bulan, antara responden debitur lancar dengan responden debitur menunggak dapat dibedakan berdasarkan ada tidaknya pelimpahan pinjaman dari unit kerja lain. Berdasarkan pengujian hipotesis dengan taraf nyata $(\alpha) 0.05$ terbukti bahwa variabel gaji, jumlah tanggungan dan pelimpahan pinjaman terbukti signifikan dalam mempengaruhi kelancaran pengembalian kredit pegawai berpenghasilan tetap baik secara inidividu maupun secara bersama-sama. 
Perbedaan penelitian terdahulu dengan penelitian saat ini adalah pertama, lokasi penelitian terdahulu di PT. BRI KC Pondok Gede, sedangkan penelitian saat ini di BMT Niaga Utama Purwakarta. Kedua, variable yang digunakan pada penelitian terdahulu menggunakan faktor-faktor yang mempengaruhi kelancaran pengembalian kredit berpenghasilan tetap (Briguna Kretap), sedangkan penelitian saat ini menggunakan variable pemahaman nasabah terdiri dari Pembiayaan Mudharabah $\left(\mathrm{X}_{1}\right)$, Pembiayaan Musyarakah $\left(\mathrm{X}_{2}\right)$, dan Pembiayaan Murabahah $\left(\mathrm{X}_{3}\right)$ pada jenis produk, serta Variabel kelancaran pembayaran angsuran (Y) di BMT Niaga Utama Purwakarta. Ketiga, objek kajian penelitian terdahulu mengkaji tentang karakteristik debitur Briguna Kretap pada BRI KC Pondok Gede berdasarkan tingkat kelancaran pengembalian kreditnya dan menganalisis faktor-faktor yang berpengaruh nyata terhadap tingkat kelancaran pengembalian Briguna Kretap pada BRI KC Pondok Gede, sedangkan penelitian saat ini menguji atau mengkaji pengaruh pembiayaan mudharabah, musyarakah dan murabahah terhadap kelancaran pembayaran angsuran. Keempat, Teknik pengambilan sampel pada penelitian terdahulu menggunakan sampling random, dan jumlah sampel yang diambil pada penelitian terdahulu sebanyak 84 orang, sedangkan Teknik pengambilan sampel pada penelitian ini menggunakan teknik purposive random sampling, dan jumlah sampel yang diambil pada penelitian ini sebanyak 34 responden.

5. Pengaruh Analisis 5c (Character, Capacity, Capital, Collateral, Condition Of Economy) Terhadap Kelancaran Pembayaran Kredit (Studi Pada Konsunen PT. Fifgroup Cabang Batu) (Samsuri, Saroh, and Zunaida 2021)
Penelitian ini bertujuan untuk mengetahui pengaruh character, capacity, capital, collateral, dan condition of economy terhadap kelancaran pembayaran kredit. Jenis penelitian ini adalah kuantitatif. Teknik pengumpulan data menggunakan teknik observasi, wawancara, kuesioner, dan dokumentasi. Jumlah sampel sebanyak 266 responden menggunakan SPSS Statistic V.25. Hasil penelitian secara parsial menunjukkan bahwa variabel character berpengaruh secara signifikan terhadap kelancaran pembayaran kredit dengan nilai nignifikan 0,000 <0,050, variabel capacity berpengaruh signifikan terhadap kelancaran pembayaran kredit dengan nilai signifikan $0,000<0,050$, variabel capital berpengaruh signifikan terhadap kelancaran pembayaran kredit dengan nilai signifikan $0,008<0,050$, variabel collateral tidak berpengaruh terhadap variabel kelancaran kredit dengan nilai signifikan 0,215>0,050, variabel condition of economy tidak berpengaruh terhadap kelancaran pembayaran kredit dengan nilai signifikan 0,166>0,050. Hasil penelitian secara simultan menunjukkan bahwa variabel character, capacity, capital, collateral dan condition of economy berpengaruh signifikan terhadap variabel kelancaran pembayaran kredit dengan nilai signifikan 0,000 0,050.

Perbedaan penelitian terdahulu dengan penelitian saat ini adalah pertama, lokasi penelitian terdahulu di PT. Fifgroup Cabang Batu, sedangkan penelitian saat ini di BMT Niaga Utama Purwakarta. Kedua, variable yang digunakan pada penelitian terdahulu menggunakan variable analisis 5c (X) terdiri dari (Character, Capacity, Capital, Collateral, Condition Of Economy) dan Kelancaran Pembayaran Kredit (Y), sedangkan penelitian saat ini menggunakan variable pemahaman nasabah terdiri dari Pembiayaan Mudharabah $\left(\mathrm{X}_{1}\right)$, Pembiayaan Musyarakah $\left(\mathrm{X}_{2}\right)$, dan Pembiayaan Murabahah $\left(\mathrm{X}_{3}\right)$ pada jenis 
produk, serta Variabel kelancaran pembayaran angsuran (Y) di BMT Niaga Utama Purwakarta. Ketiga, objek kajian penelitian terdahulu mengkaji tentang pengaruh character, capacity, capital, collateral, dan condition of economy terhadap kelancaran pembayaran kredit, sedangkan penelitian saat ini menguji atau mengkaji pengaruh pembiayaan mudharabah, musyarakah dan murabahah terhadap kelancaran pembayaran angsuran. Keempat, Teknik pengambilan sampel pada penelitian terdahulu menggunakan sampling slovin, dan jumlah sampel yang diambil pada penelitian terdahulu sebanyak 266 orang, sedangkan Teknik pengambilan sampel pada penelitian ini menggunakan teknik purposive random sampling, dan jumlah sampel yang diambil pada penelitian ini sebanyak 34 responden.

\section{METODOLOGI PENELITIAN A.Pendekatan dan Metode Penelitian}

Penelitian ini menggunakan jenis pendekatan deskriptif kuantitatif dimana metode ini bertujuan untuk menganalisis keterkaitan variabel satu dengan variabel yang lain berdasarkan koefesien pengaruh dan untuk menganalisis keterkaitan variabel tersebut secara simultan.

\section{B. Lokasi dan Waktu Penelitian}

Lokasi penelitian adalah BMT Niaga Utama yang berada di kabupaten Purwakarta dengan periode waktu selama 3 tahun terhitung dari 2017 sampai dengan 2020 dengan populasi seluruh nasabah dari BMT Niaga Utama Purwakarta yang tercatat memiliki akad pembiayaan.

Sampel yang digunakan pada peneliti ini adalah sebanyak 34 responden yang ditentukan dengan teknik purposive random sampling. Adapun rincian dari 34 responden tersebut adalah nasabah dengan akad pembiayaan mudharabah sebanyak 10 orang, nasabah pembiayaan musyarakah 8 orang sedangkan nasabah pembiayaan murabahah 16 orang (Zaenuri and Kristyassari 2007).

Penentuan sample yang digunakan dalam penelitian ini adalah teori roscoe dengan ukuran sampel yang baik yaitu diantara 30 sampai 500 elemen dan teori Krejcie dan Morgan (1970) cara menentukan sampel adalah sebagai berikut.

\section{Tabel 3.1}

Cara Menentukan Sampel

\begin{tabular}{|c|c|c|c|c|c|}
\hline $\begin{array}{c}\text { Popula } \\
\text { si (N) }\end{array}$ & $\begin{array}{c}\text { Sampel } \\
(\mathbf{n})\end{array}$ & $\begin{array}{c}\text { Polpulasi } \\
(\mathbf{N})\end{array}$ & $\begin{array}{c}\text { Sampel } \\
(\mathbf{n})\end{array}$ & $\begin{array}{c}\text { Populasi } \\
(\mathbf{N})\end{array}$ & $\begin{array}{c}\text { Samp } \\
\text { el (n) }\end{array}$ \\
\hline 10 & 10 & 220 & 140 & 1200 & 291 \\
\hline 15 & 14 & 230 & 144 & 1300 & 297 \\
\hline 20 & 19 & 240 & 148 & 1400 & 302 \\
\hline 25 & 24 & 250 & 152 & 1500 & 306 \\
\hline 30 & 28 & 260 & 155 & 1600 & 310 \\
\hline 35 & 32 & 270 & 159 & 1700 & 313 \\
\hline
\end{tabular}

Adapaun sumber data yang gunakan adalah data primer dan data sekunder. Sedangkan teknik pengumpulan data yang digunakan dalam penelitian ini adalah meliputi wawancara, observasi dan penyebaran angket kuesioner dengan menggunkan skala likert dengan skore penilaian Sangat Setuju (SS) $=$ 5, Setuju $(S)=4$, Cukup Setuju $(C S)=3$, Kurang Setuju (KS) $=2$ dan Tidak Setuju (TS) $=1$. Uji Instrumen yang digunakan dalam penelitian ini meliputi uji validasi, uji reliabilitas instrument, statistik non parametrik dan tes statistik non parametrik. Uji normalitas data yang meliputi uji kolmogorov-smirnov test, dan uji pengaruh spearman.

\section{HASIL DAN PEMBAHASAN}

A. Hasil Uji Statistik

1.Hasil Uji Sparman Pemahaman Nasabah Pada Produk Mudharabah Terhadap Kelancaran Pembayaran Angsuran Tabel 4.1

Hasil Uji Spearman

\begin{tabular}{|c|c|c|c|c|c|c|}
\hline No. & $\begin{array}{c}\text { Pemahaman } \\
\text { nasabah (X) }\end{array}$ & $\begin{array}{c}\text { Kelancaran } \\
\text { Pembayaran } \\
\text { Angsuran (Y) }\end{array}$ & $\mathrm{Rx}$ & $\mathrm{Ry}$ & $\begin{array}{c}\mathrm{d}= \\
\mathrm{Rx}- \\
\mathrm{Ry}\end{array}$ & $\mathrm{d}^{2}$ \\
\hline 1 & 42 & 40 & 8 & 10 & -2 & 4 \\
\hline 2 & 41 & 43 & 9 & 8,5 & 1,5 & 2,25 \\
\hline 3 & 39 & 43 & 10 & 8,5 & 2,5 & 6,25 \\
\hline
\end{tabular}




\begin{tabular}{|c|c|c|c|c|c|c|}
\hline No. & $\begin{array}{l}\text { Pemahaman } \\
\text { nasabah (X) }\end{array}$ & $\begin{array}{c}\text { Kelancaran } \\
\text { Pembayaran } \\
\text { Angsuran (Y) }\end{array}$ & $\mathrm{Rx}$ & Ry & $\begin{array}{l}\mathrm{d}= \\
\mathrm{Rx}- \\
\mathrm{Ry}\end{array}$ & $\mathrm{d}^{2}$ \\
\hline 4 & 43 & 45 & 7 & 7 & 0 & 0 \\
\hline 5 & 48 & 48 & 2 & 3 & -1 & 1 \\
\hline 6 & 45 & 48 & 5 & 3 & 2 & 4 \\
\hline 7 & 45 & 48 & 5 & 3 & 2 & 4 \\
\hline 8 & 47 & 47 & 3 & 5 & -2 & 4 \\
\hline 9 & 45 & 46 & 5 & 6 & -1 & 1 \\
\hline \multirow[t]{2}{*}{10} & 49 & 50 & 1 & 1 & 0 & 0 \\
\hline & & & \multicolumn{3}{|c|}{ Jumlah } & 26,5 \\
\hline
\end{tabular}

Hasil yang diperoleh dari uji validitas dan reliabilitas adalah rs hitung $(0,84)>$ rs tabel $(0,648)$, jadi kesimpulannya pemahaman nasabah Mudharabah dan Musyarakah mempunyai hubungan yang berpengaruh signifikan dengan kelancaran pembayaran angsuran di Koperasi BMT Niaga Utama Purwakarta. Hal ini juga dibuktikan dengan hasil penelitian Maryam dengan hasil penelitian pemberian pembiayaan terhadap perkembangan usaha nasabah memiliki pengaruh positif dan signifikan dengan nilai koefisien jalur (R) sebesar 0,717 dan $\mathrm{p}=0,001$ $(\mathrm{p}<0,05)$ : terhadap pengaruh positif dan jalur signifikan antara perkembangan usaha terhadap peningkatan pendapatan nasabah dengan jalur $\mathrm{R}$ sebesar 0,535 dan $\mathrm{p}=0,001(\mathrm{p}<0,05) \quad$ terhadap pengaruh pemberian pembiayaan Mudharabah dan musyarakah melalui perkembangan usaha.

2.Hasil Uji Sparman Pengaruh Pemahaman Nasabah Pada Produk Musyarakah Terhadap Kelancaran Pembayaran Angsuran Di BMT Niaga Utama Purwakarta

Tabel 4.2

Hasil Uji Spearman

\begin{tabular}{|c|c|c|c|c|c|c|}
\hline No. & $\begin{array}{c}\text { Pemahaman } \\
\text { Nasabah } \\
\text { Musyarakah (X) }\end{array}$ & $\begin{array}{c}\text { Kelancaran } \\
\text { Pembayaran } \\
\text { Angsuran (Y) }\end{array}$ & $\mathrm{Rx}$ & $\mathrm{Ry}$ & $\begin{array}{c}\mathrm{d}= \\
\mathrm{Rx}- \\
\mathrm{Ry}\end{array}$ & $\mathrm{d}^{2}$ \\
\hline 1 & 37 & 38 & 7 & 7 & 0 & 0 \\
\hline 2 & 37 & 34 & 7 & 8 & -1 & 1 \\
\hline 3 & 41 & 41 & 3 & 4 & -1 & 1 \\
\hline 4 & 40 & 40 & 4 & 5,5 & $-1,5$ & 2,25 \\
\hline 5 & 39 & 40 & 5 & 5,5 & $-0,5$ & 0,25 \\
\hline 6 & 43 & 50 & 2 & 1 & 1 & 1 \\
\hline 7 & 44 & 42 & 1 & 3 & -2 & 4 \\
\hline 8 & 38 & 46 & 6 & 2 & 4 & 16 \\
\hline \multicolumn{5}{|r|}{ Jumlah } \\
\hline
\end{tabular}

Menghitung $r_{s}$ hitung dan $r_{s}$ tabel

$$
\begin{aligned}
& r_{\text {s hitung }}=0,697 \\
& r_{\text {s tabel }}=0,738
\end{aligned}
$$

Membandingkan $r_{s}$ hitung dengan $r_{s}$ tabe

Berdasarkan kaidah pengujian Ho diterima, karena $r_{s}$ hitung $(0,697)<r_{s}$ tabel $(0,738)$, jadi kesimpulannya pemahaman nasabah musyarakah tidak mempunyai hubungan yang signifikan dengan kelancaran pembayaran angsuran di Koperasi BMT Niaga Utama Purwakarta. Terbukti dengan jumlah nasabah pembiayaan musyarakah yang masih sedikit.

\section{Hasil Uji Pengaruh Pemahaman Nasabah}

Pada Produk Murabahah Terhadap

Kelancaran Pembayaran Angsuran Di BMT Niaga Utama Purwakarta

Untuk mengetahui pengaruh pemahaman nasabah murabahah terhadap kelancaran pembayaran angsuran peneliti menggunakan SPSS.16

\section{Tabel 4.3}

Hasil Uji Regresi Linier

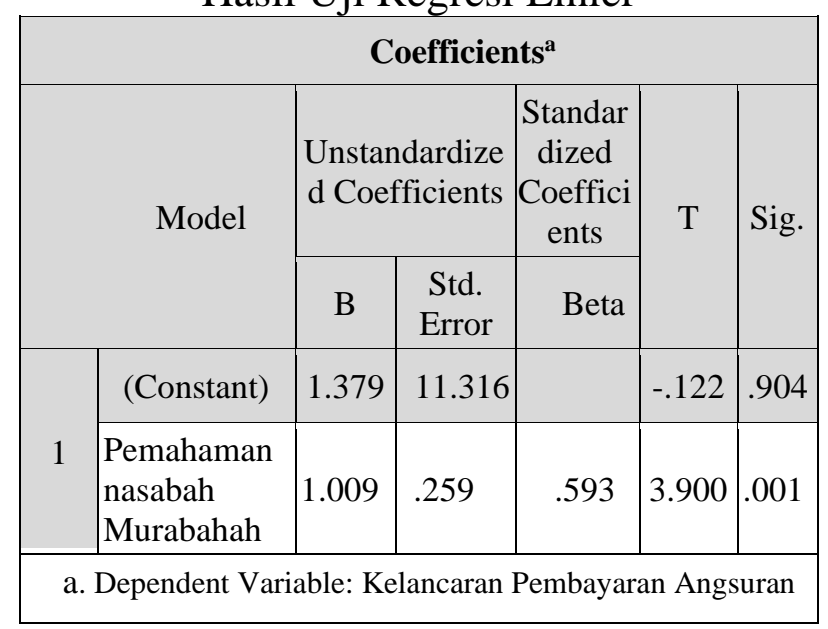

Berdasarkan data diatas diketahui bahwa:

1) Semua indikator variabel dinyatakan valid dan realibel. Hal ini terbukti bahwa nilai Corrected Item Total lebih besar dari 0.3 yang memiliki arti konstruk yang kuat, dan bermakna realibel karenakan nilai alpha Cronbach (r11) > 0,6 . 
2) Dari tabel Anova diperoleh dengan nilai nilai sebesar 15,212 dengan tingkat signifikansi 0,001. Oleh karena probabilitas $(0,001)$ jauh lebih kecil dari 0,05 (dalam kasus ini menggunakan taraf signifikansi atau $\mathrm{a}=5 \%$ ), maka model regresi bisa dipakai untuk memprediksi kelancaran pembayaran angsuran. Nilai sebesar 15,212> Sebesar 3,37 Maka $\mathrm{H}_{\mathrm{o}}$ ditolak dan $\mathrm{H}_{\mathrm{a}}$ diterima.

3) Dari tabel Coefficientsa diperoleh Uji T diperoleh nilai Thitung sebesar 3,900 dengan nilai probabilitas (sig.) sebesar 0.001. Nilai Thitung $(3,900)>$ Ttabel $(1,70)$, dan nilai sig. $(0.001)<0.05$, maka Ho ditolak dan Ha diterima, hal ini berarti pemahaman nasabah Murabahah berpengaruh signifikan terhadap kelancaran pembayaran angsuran yang juga dibuktikan dengan nilai uji t dimana $\mathrm{H}_{\mathrm{o}}$ ditolak dan $\mathrm{H}_{\mathrm{a}}$ diterima dengan perhitungan $t_{\text {hitung }}>t_{\text {tabel }}$ yaitu $t_{\text {hitung }}$ diperoleh sebesar 5,992 sementara $t_{\text {tabel }}$ diperoleh sebesar 2,0392 berarti berpengaruh signifikan antara pinjaman terhadap pendapatan.

\section{Hasil Uji Mann Whitney Pengaruh Rata-}

Rata Pemahaman Nasabah Terhadap

Kelancaran Pembayaran Angsuran Di

BMT Niaga Utama Purwakarta

Tahap ini dilakukan untuk mengetahui tingkat rata-rata pengaruh pemahaman nasabah mudharabah, musyarakah dan murabahah terhadap kelancaran pembayaran angsuran, di uji dengan menggunkan uji statistic sampel kecil (Mann Whitney). Tabel penolong untuk mengidentifikasi nilai R1 dan R2 dalam uji Mann Whitney Sampel kecil.

Tabel 4.3

Uji Mann Whitney Sampel Kecil

\begin{tabular}{|c|c|c|c|c|c|c|}
\hline $\begin{array}{l}\text { Sumb } \\
\text { er } \\
\text { Data }\end{array}$ & $\begin{array}{l}\text { Sampel } \\
\text { Gabungan } \\
\left(\mathrm{X}_{1}, \mathrm{X}_{1}\right)\end{array}$ & $\begin{array}{l}\text { Rank } \\
(\mathrm{R})\end{array}$ & $\begin{array}{l}\text { Sampel } \\
1\left(\mathrm{X}_{1}\right)\end{array}$ & $\begin{array}{l}\text { Rank } \\
\mathrm{R}_{1}\end{array}$ & $\begin{array}{l}\text { Sampel } \\
\text { II } \mathrm{X}_{1}\end{array}$ & $\begin{array}{l}\text { Rank } \\
\mathrm{R}_{2}\end{array}$ \\
\hline 1. & 34 & 1 & 40 & 4 & 38 & 2 \\
\hline
\end{tabular}

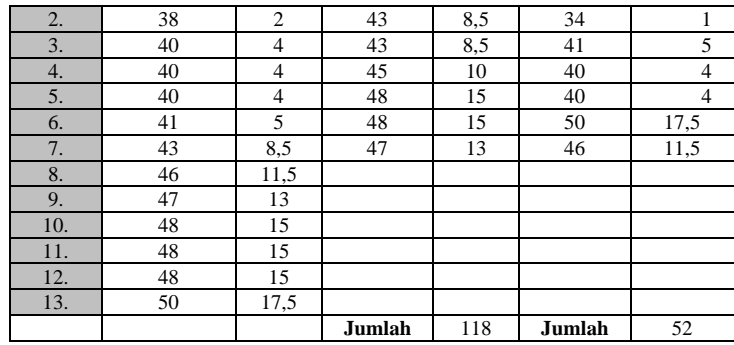

Berdasarkan hasil pengujian tersebut diperoleh nilai $U_{\text {hitung }}$ lebih besar dari $U_{\text {tabel }}$ dengan demikian dapat disimpulkan bahwa tidak ada perbedaan antara pemahaman nasabah pada produk murabahah, produk mudharabah dan produk musyarakah terhadap kelancaran pembayaran angsuran.

\section{B. Pembahasan}

\section{Pengaruh Pemahaman Nasabah Pada Produk Mudharabah Terhadap \\ Kelancaran Pembayaran Angsuran Di BMT Niaga Utama Purwakarta}

Hasil yang diperoleh dari uji tersebut adalah rs hitung $(0,84)>$ rs tabel $(0,648)$, jadi kesimpulannya pemahaman nasabah mudharabah mempunyai hubungan yang berpengaruh signifikan dengan kelancaran pembayaran angsuran di Koperasi BMT Niaga Utama Purwakarta. Hal ini juga dibuktikan dengan hasil penelitian suryati dengan hasil penelitian pemberian pembiayaan terhadap perkembangan usaha nasabah memiliki pengaruh positif dan signifikan dengan nilai koefisien jalur $(\mathrm{R})$ sebesar 0,717 dan $\mathrm{p}=0,001(\mathrm{p}<0,05)$ : terhadap pengaruh positif dan jalur signifikan antara perkembangan usaha terhadap peningkatan pendapatan nasabah dengan jalur $\mathrm{R}$ sebesar 0,535 dan $\mathrm{p}=0,001(\mathrm{p}<0,05)$ terhadap pengaruh pemberian pembiayaan mudharabah melalui perkembangan usaha.

\section{Pengaruh Pemahaman Nasabah Pada Produk Musyarakah Terhadap}


Kelancaran Pembayaran Angsuran Di BMT Niaga Utama Purwakarta

Pemahaman nasabah musyarakah terhadap kelancaran pembayaran angsuran rs hitung $(0,697)<$ rs tabel $(0,738)$, jadi kesimpulannya pemahaman nasabah musyarakah tidak mempunyai hubungan yang berpengaruh signifikan dengan kelancaran pemabayaran angsuran nasabah Koperasi BMT Niaga Utama Purwakarta. Terbukti dengan jumlah nasabah pembiayaan musyarakah yang masih sedikit karena masyarakat masih belum berminat menggunakan produk pembiayaan tersebut.

\section{Pengaruh Pemahaman Nasabah Pada Produk Murabahah Terhadap \\ Kelancaran Pembayaran Angsuran Di BMT Niaga Utama Purwakarta}

Pengaruh pemahaman nasabah murabahah terhadap kelancaran pembayaran angsuran peneliti menggunakan SPSS.16 dan diperoleh hasil sebagai berikut:

Untuk data yang diperoleh peneliti dari hasil koesioner yang telah disebar kepada nasabah terbukti semua indikator variabel dinyatakan valid dan realibel. Hal ini terbukti bahwa nilai Corrected Item Total lebih besar dari 0.3 yang berarti memiliki konstruk yang kuat, sedangkan dikatakan realibel dikarenakan nilai alpha Cronbach $(\mathrm{r} 11)>0,6$ maka variabel setiap indikator tersebut dikatakan realibel.

Dari tabel Anova diperoleh dengan nilai nilai sebesar 15,212 dengan tingkat signifikansi 0,001 . Oleh karena probabilitas $(0,001)$ jauh lebih kecil dari 0,05 (dalam kasus ini menggunakan taraf signifikansi atau $\mathrm{a}=$ 5\%), maka model regresi bisa dipakai untuk memprediksi kelancaran pembayaran angsuran. Nilai sebesar 15,212 > Sebesar 3,37 Maka Ho ditolak dan Ha diterima, hal ini berarti pemahaman nasabah murabahah berpengaruh signifikan terhadap kelancaran pembayaran angsuran.

Dari tabel Coefficientsa diperoleh Uji T diperoleh nilai Thitung sebesar 3,900 dengan nilai probabilitas (sig.) sebesar 0.001. Nilai Thitung $(3,900)>$ Ttabel $(1,70)$, dan nilai sig. $(0.001)<0.05$, maka Ho ditolak dan Ha diterima, hal ini berarti pemahaman nasabah murabahah berpengaruh signifikan terhadap kelancaran pembayaran angsuran. Hal ini juga dibuktikan dengan hasil penelitian Dewi Gilang Maharani yang menunjukkan uji $t$ menunjukan Ho ditolak dan Ha diterima dengan perhitungan thitung $>$ ttabel yaitu thitung diperoleh sebesar 5,992 sementara ttabel diperoleh sebesar 2,0392 berarti berpengaruh signifikan antara pinjaman terhadap pendapatan.

\section{Pengaruh Rata-Rata Pemahaman Nasabah Terhadap Kelancaran Pembayaran Angsuran Di BMT Niaga Utama Purwakarta}

Tingkat rata-rata pengaruh pemahaman nasabah mudharabah, musyarakah dan murabahah terhadap kelancaran pembayaran angsuran, di uji dengan menggunkan uji statistic sampel kecil (Mann Whitney) yang hasilnya Karena nilai Uhitung lebih besar dari Utabel maka kesimpulannya adalah tidak ada perbedaan antara pengaruh kelancaran pembayaran angsuran yang memperoleh pemahaman nasabah mudharabah, pemahaman nasabah musyarakah, dan pemahaman nasabah murabahah. Jadi, meskipun pemahaman nasabah mudharabah mempunyai hubungan yang signifikan sedangan pemahaman nasabah musyarakah dan pemahaman nasabah murabahah tidak signifikan dengan kelancaran pembayaran angsuran tetapi memiliki tingkat rata-rata sama-sama berpengaruh.

\section{KESIMPULAN}


Berdasarkan dari hasil penelitian diatas maka dapat disimpulkan bahwa Pemahaman nasabah mudharabah mempunyai hubungan yang berpengaruh signifikan terhadap kelancaran pembayaran angsuran di koperasi BMT Niaga Utama Purwakarta. Hal ini dikarenakan $r_{s}$ hitung lebih besar dari $r_{s}$ tabel, secara riil di lapangan nasabah memanfaatkan pembiayaan ini untuk perkembangan usaha mereka.

Pengaruh pemahaman nasabah musyarakah terhadap kelancaran pembayaran angsuran memiliki hubungan yang tidak berpengaruh signifikan. Karena rs ${ }_{\text {hitung lebih }}$ kecil dari rstabel. Hal ini terjadi karena dalam praktiknya di lapangan minat nasabah untuk menggunakan produk ini masih sedikit karena permasalan bagi hasil yang harus diberikan nasabah kepada koperasi tidak sama setiap bulannya. Oleh karena itu nasabah kurang berminat dengan produk pembiayaan ini untuk usaha mereka.

Hubungan antara pemahaman nasabah murababah memiliki tingkat nilai s sig.(2tailed) sebesar 0,001 yang lebih kecil dari level of significant $(\alpha) 5 \%$ maka diterima $\mathrm{Ha}$ yang berarti hipotesis yang diajukan adalah teruji bahwa ada hubungan yang berpengaruh signifikan antara pemahaman nasabah murabahah terhadap kelancaran pembayaran angsuran di BMT Niaga Utama Purwakarta. Hasil diperoleh $(15,212)>(3,37)$ maka Ha diterima, Hasil Uji T diperoleh $\mathrm{T}_{\text {hitung }}(3,900)>$ $\mathrm{T}_{\text {tabel }}(1,70)$ maka Ha diterima, yang berarti pemahaman nasabah murabahah berpengaruh signifikan terhadap kelancaran pembayaran angsuran.

Pengaruh rata-rata antara pemahaman nasabah mudharabah, musyarakah dan murabahah tidak ada perbedaaan antara pengaruh kelancaran pembayaran angsuran pembiayaan mudharabah, musyarakah dan murabahah. Karena nilai $\mathrm{U}_{\text {hitung }}$ lebih besar dari $\mathrm{U}_{\text {tabel. }}$

\section{DAFTAR PUSTAKA}

Al-Hadi Al-Quran Terjemahan Per Kata Latin Dan Kode Tajwid. 2013. Jakarta.

Alhifni, Anas, and Nurul Huda. 2015. "Kinerja LKMS Dalam Mendukung Kegiatan Ekonomi Rakyat Berbasis Pesantren (Studi Pondok Pesantren Darut Tauhid Dan BMT Darut Tauhid)." Jurnal Aplikasi Manajemen 13, no. 4: 597.

An-Nasa'i, Ahmad Abi Adirrahman Bin Suaib Ali. n.d. Sunan An-Nasa'i. Riyad: Maktabah Al-Ma'arif.

Apriana, Shendy, Dwi Wahyu Artiningsih, and Irwansyah Irwansyah. 2017. "Analisis Pengaruh Prasyarat Kredit (5C) Terhadap Kelancaran Pembayaran Angsuran Nasabah Di Bank Kalsel Unit Sentra Antasari Banjarmasin." Jurnal Bisnis Dan Pembangunan 6, no. 1: 10-18.

Bakry, Muammar, and Rahman Ambo Masse. 2020. "Diskursus Prinsip Syariah Dalam Akad Transaksi Murabahah Pada Perbankan Syariah Di Makasar." Istinbath 19, no. 1 (July). https://doi.org/10.20414/ijhi.v19i1.202.

Dewi, Ernanda Kusuma, and Ayu Astari. 2018. "Peran Pembiayaan Mudharabah Dalam Pengembangan Kinerja Usaha Mikro Pada BMT (Baitul Maal Wat Tamwil)." Law and Justice 2, no. 2: 113.

Hamidah, Siti, and Prayudo Eri Yandono. 2016. "Akad Pembiayaan Mudharabah Menurut Pemahaman Nasabah Baitul Maal Wat Tamwil Di Tongas Probolinggo.” Jurisdictie 7, no. 2: 10.

Hasan, Maryam. 2017. "Prediksi Tingkat Kelancaran Pembayaran Kredit Bank Menggunakan Algoritma Naive Bayes Berbasis Forward Selection." ILKOM Jurnal Ilmiah 9, no. 3: 317-24. 
Hidayat, Solikhul. 2013. "Penerapan Akuntansi Syariah Pada BMT Lisa Sejahtera Jepara." Jurnal Dinamika Ekonomi \& Bisnis 10, no. 2 (October). https://doi.org/10.34001/JDEB.V10I2.83.

Hutagalung, Muhammad Abrar Kasmin, Muhammad Ridwan, Nita Yulia, Fatmah Nasution, and Nirma Sari Harahap. 2021. "Pengenalan Tentang Akad Pembiayaan Di Dunia Bisnis Secara Syariah." PUBLIDIMAS (Publikasi Pengabdian Masyarakat) 1, no. 1: 13-20.

Ibrahim, Azharsyah, and Arinal Rahmati. 2017. "Analisis Solutif Penyelesaian Pembiayaan Bermasalah Di Bank Syariah: Kajian Pada Produk Murabahah Di Bank Muamalat Indonesia Banda Aceh." Iqtishadia: Jurnal Kajian Ekonomi Dan Bisnis Islam STAIN Kudus 10, no. 1: 71-96.

Indonesia, Ikatan Bankir. 2014. Memahami Bisnis Bank Syariah. Bandung: Gramedia Pustaka Utama.

Kementerian Agama. 2010. Al-Qur'an Dan Terrjemahannya. Bogor: Lembaga Percetakan Al-Qur'an.

Lisdawami, Indi Masita, and Imron Mawardi. 2017. "Pengembangan Produk Funding KSPPS BMT Amanah Ummah Jawa Timur." Jurnal Ekonomi Syariah Teori Dan Terapan 4, no. 11: 889.

Natalia, Vanny Arivianti, Supri Wahyudi Utomo, and Juli Murwani. 2019. "Pengaruh Pinjaman Dana Dan Jenis Usaha Terhadap Kelancaran Pembayaran Kredit Di Bank BTN Madiun.” In FIPA: Forum Ilmiah Pendidikan Akuntansi. Vol. 7.

Romdhoni, Abdul Haris, and Dita Ratna Sari. 2018. "Pengaruh Pengetahuan, Kualitas Pelayanan, Produk, Dan Religiusitas
Terhadap Minat Nasabah Untuk Menggunakan Produk Simpanan Pada Lembaga Keuangan Mikro Syariah." Jurnal Ilmiah Ekonomi Islam 4, no. 02 (July): 136. https://doi.org/10.29040/jiei.v4i02.307.

Samsuri, Mega Rahayu Putri, Siti Saroh, and Daris Zunaida. 2021. "Pengaruh Analisis 5c (Character, Capacity, Capital, Collateral, Condition Of Economy) Terhadap Kelancaran Pembayaran Kredit (Studi Pada Konsunen PT. Fifgroup Cabang Batu)." JIAGABI (Jurnal Ilmu Administrasi Niaga/Bisnis) 10, no. 2: 8893.

Singgih, Subekti, Anne Mardiana, and others. 2018. "Faktor-Faktor Yang Mempengaruhi Kelancaran Pengembalian Kredit Berpenghasilan Tetap (Briguna Kretap)." Jurnal Akuntansi Dan Manajemen 15, no. 02: $113-28$.

Usanti, Trisadini Prasastinah. 2013. "Konsep Utang Dalam Akad Pembiayaan Mudharabah Pada Bank Syariah." ADIL: Jurnal Hukum 4, no. 2: 308-29.

Zaenuri, Muhammad, and Bening Kristyassari. 2007. "Analisis Pengaruh Sistem Bagihasil, Pelayanan Dan Lokasi Terhadap Keputusan Memilih Produk Bmt Al-Hikmah Bangsri." Jurnal Dinamika Ekonomi \& Bisnis 4, no. 1: 7184. 